\title{
Immunoelectrophoretic studies on human small intestinal brush border proteins-amount of lactase protein in adult-type hypolactasia
}

\author{
H SKOVBJERG, E GUDMAND-HØYER, AND H J FENGER
}

From the Department of Biochemistry C, The Panum Institute, University of Copenhagen, Denmark, the Medical-gastroenterological Department C, Herlev Hospital, University of Copenhagen, Denmark, and the Surgical Department, Queen Ingrids Hospital, Godthåb, Greenland

SUMmARY Jejunal biopsies from 15 Greenlandic and three Danish patients with adult type hypolactasia and nine Greenlandic and 15 Danish patients with normal lactase activity were analysed quantitatively for lactase protein by crossed immunoelectrophoresis. A constant correlation between the amount of lactase activity and immunologically reactive lactase protein was demonstrated irrespective of the lactase activity level. As immunoelectrophoresis expresses the amount of enzyme protein independent of the enzymatic activity, it is concluded that the low enzymatic activity in adults with hypolactasia is caused by a low amount of lactase and not by a modified inactive enzyme.

Adult type hypolactasia is often considered to be a normal condition in man, as most of the world's ethnic groups including Greenlandic Eskimos ${ }^{1}$ have a $70-95 \%$ prevalence of hypolactasia. Only whites in Northern Europe and white North Americans appear to maintain high levels of lactase throughout life.

The condition was first described in $1963 . .^{23}$ The reason for the low lactase activity may be either synthesis of a defect protein or decreased synthesis of a normal protein. To distinguish between these possibilities Crane et al. ${ }^{4}$ and Freiburghaus et al. ${ }^{5}$ prepared brush border membranes from peroral intestinal biopsies and analysed the constituent proteins by sodium dodecyl sulphate electrophoresis. Their conclusion was that adults with hypolactasia probably synthesise a decreased amount of lactase protein but the conclusion was in part limited by their procedure, which involves loss of material during the membrane preparation procedure and a possible poor separation of lactase from other unknown proteins.

A precise answer whether lactase protein is qualitatively altered in hypolactasia has not yet been given. This had been considered possible by using specific antibodies against the enzyme ${ }^{6}$ but, because of the great lability of lactase during purification procedures, this has until now not been done.

Received for publication 4 September 1979
We have previously described ${ }^{7}$ quantitative immunoelectrophoresis of proteins from single, unfractionated, small intestinal biopsies against a specific brush border protein antiserum. As the lactase precipitate was identified by enzymatic staining and the analysis determines the amount of immunological reactive protein, the application of this method makes a quantitative approach possible without the limitations of earlier investigations. In the present paper we describe the results of such an investigation on 18 hypolactasia patients and 24 controls.

\section{Methods}

PATIENTS

Twenty-four Greenlandic patients from the surgical department, Queen Ingrids Hospital, Godthåb, were included in the study. Small pieces from the proximal $20 \mathrm{~cm}$ of jejunum removed during upper abdominal surgery were used. In addition pieces from the same part of jejunum of 18 Danish patient subjected to jejunal-ileal shunt operation (part of the Danish Obesity Project) were included. All samples were frozen immediately after removal. Fifteen Greenlandic patients and three Danish patients had hypolactasia defined as low lactase activity $(<9 \mathrm{U} / \mathrm{g}$ protein) with normal activities for the other disaccharidases, and histologically normal jejunal biop- 
Table 1 Greenlandic patients

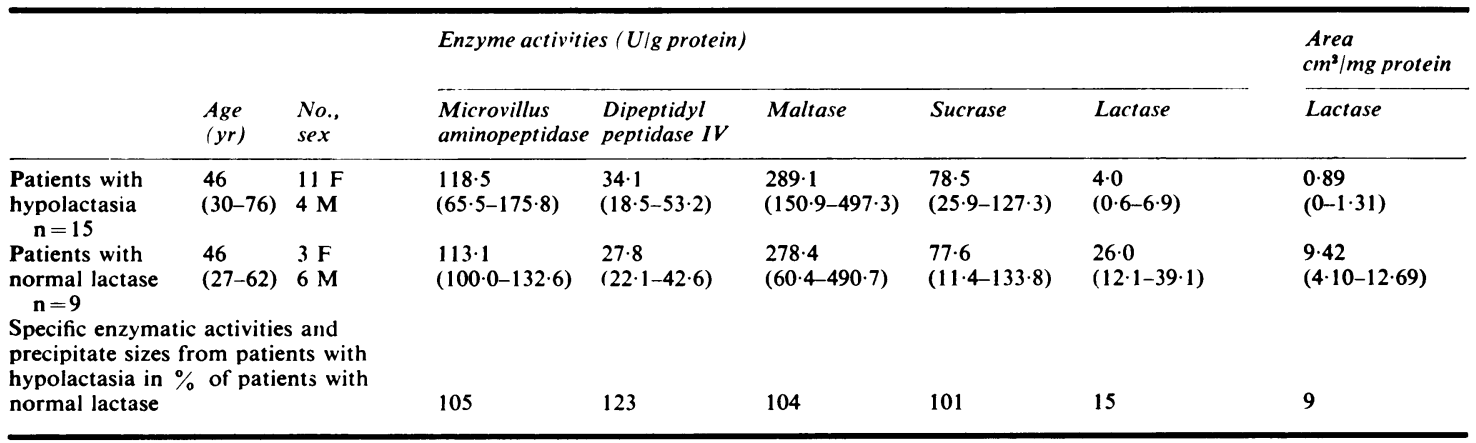

Age, specific enzymatic activities, and specific precipitate sizes expressed as mean values. Numbers in parentheses are ranges.

sies. ${ }^{8}$ The rest of the patients had normal lactase as well as the other enzymatic activities that were studied and they served as controls. Age and sex distribution for the Greenlandic patients are given in Table 1 and for the Danish patients in Table 2.

\section{TECHNIQUES}

Mucosal samples (3-16 mg) were obtained by carefully scraping the intestinal pieces. Brush border proteins from each sample were solubilised with Triton $\mathrm{X}-100$ and papain and quantified by crossed immunoelectrophoresis as described earlier. ${ }^{7}$ To summarise briefly: each sample was homogenised in $40 \mu \mathrm{l}$ of a $2 \%$ Triton X-100 solution and incubated for one hour at $4^{\circ} \mathrm{C}$. Papain at a final concentration of $2.5 \mathrm{mg} / \mathrm{ml}$ was added and $15 \mu \mathrm{l}$ removed immediately for enzymatic analysis. The rest of the homogenate was incubated for 15 minutes at $37^{\circ} \mathrm{C}$, and subsequently centrifuged at $50000 \times g$ for two hours. Ten microlitres of the supernatant was analysed in crossed immunoelectrophoresis. After completing the electrophoresis the lactase precipitate was first stained by an enzymatic method, using lactose or phlorizin as substrate ${ }^{9}$ and then all pre- cipitates were stained by Coomassie Brilliant Blue $R$ 250. Lactase (EC 3.2.1.23), sucrase (EC 3.2.1.48) and maltase (EC 3.2.1.20) activities were assayed in the homogenate using their corresponding disaccharides as substrates. ${ }^{10}$ The activities of microvillus aminopeptidase (microsomal, EC 3.4.11.2) and dipeptidyl peptidase IV (EC 3.4.14.X) were determined using L-alanine-p-nitroanilide and glycylL-proline-p-nitroanilide respectively as substrate. ${ }^{9}$ The protein concentration of the homogenate was measured $^{11}$ in a small sample taken before addition of papain.

\section{Results}

Table 1 and Table 2 show the specific activities of the disaccharidases and the peptidases in Greenlandic and Danish patients respectively. In the Greenlandic group the specific lactase activity in the patients with hypolactasia was reduced to $15 \%$ of the activity in the control group, while the three Danish patients displayed a higher percent $(20 \%)$ lactase activity. The sucrase and maltase activities do not differ between the hypolactasia and the

Table 2 Danish patients

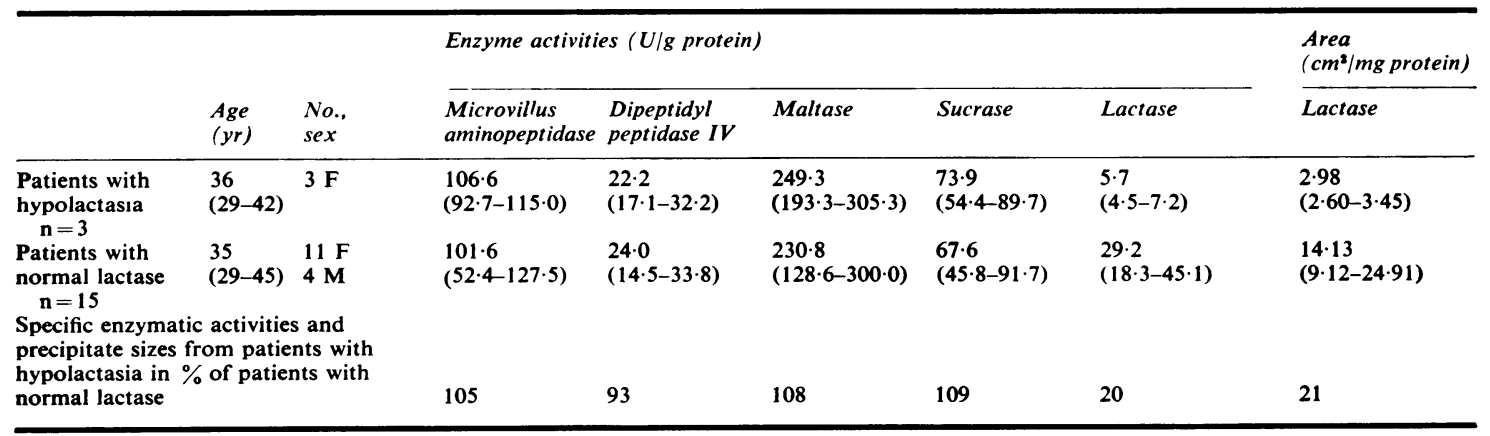

Age, specific enzymatic activities, and specific precipitate sizes expressed as mean values. Numbers in parentheses are ranges. 


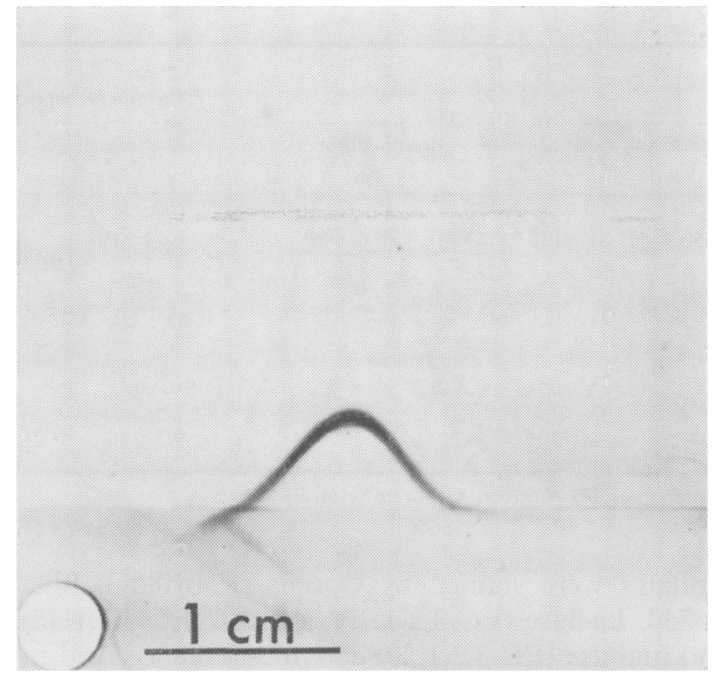

Fig. 1 The lactase precipitate from a patient with hypolactasia $(4 \cdot 2 \mathrm{U} / \mathrm{g}$ protein) after enzymatic staining using phlorizin as substrate. The IgG concentration in the gel was $30 \mu \mathrm{g} / \mathrm{cm}^{2}$.

control groups and this is also true for the two brush border peptidases that were studied.

\section{ELECTROPHORETIC PATTERN}

The lactase precipitate is visible after enzymatic staining (Fig. 1) and after staining with Coomassie Blue. No other precipitates hydrolyse lactose or phlorizin. Figure 2a-b shows the immunoelectrophoretic pattern from one patient with normal lactase and one patient with hypolactasia. These patterns are typical for all the biopsies that were studied. Compared with the precipitate pattern from normal biopsies the lactase precipitate from hypolactasia biopsies is low in relation to the other precipitates. The lactase protein has the same migration rate in the first dimension electrophoresis in all biopsies and the immunoprecipitate is symmetrical in both normal and hypolactasia biopsies indicating unchanged charge properties of the enzyme.

\section{ENZYMATIC ACTIVITY COMPARED WITH}

PRECIPITATE SIZE

The relation between lactase activity and amount of lactase protein estimated as the area under the lactase precipitate is shown in Fig. 3a (Greenlandic patients) and $3 \mathrm{~b}$ (Danish patients). There seems to be an identical relation between enzymatic activity and precipitate area in normals and in adult-type hypolactasia patients. This is also reflected in Table 1 and Table 2 where the mean values of specific lactase activity and specific area size for the hypolactasia patients are decreased to about the same low level $(15 \%-9 \%$ for Greenlandic and $20 \%-21 \%$ for Danish patients) when compared with controls. Acid $\beta$-galactosidase present in our biopsies might increase the specific lactase activity in the hypolactasia patients relatively more than in the controls without affecting the size of the precipitates. Preliminary experiments including the acid $\beta$-galactosidase inhibitor p-chloro-mercuri-benzoate in the lactase assay ${ }^{12}$ indicate that the proportion between
Fig. 2 Crossed immunoelectrophoresis of solubilised biopsies from (a) a patient with normal lactase activity (39.1 U/g protein) and $(b)$ a patient with hypolactasia ( $4.4 \mathrm{U} / \mathrm{g}$ protein). The biopsies were treated as described in the Methods section. Ten microlitres of the supernatant was applied in the well. The IgG concentration in the gel was $30 \mu \mathrm{g} / \mathrm{cm}^{2}$. When the electrophoresis was finished the plates were dried and stained with Coomassie Blue. L: lactasephlorizinhydrolase. S: sucraseisomaltase. $M$ : maltase.

A: microvillus aminopeptidase. $G$ : dipeptidyl peptidase $I V$.

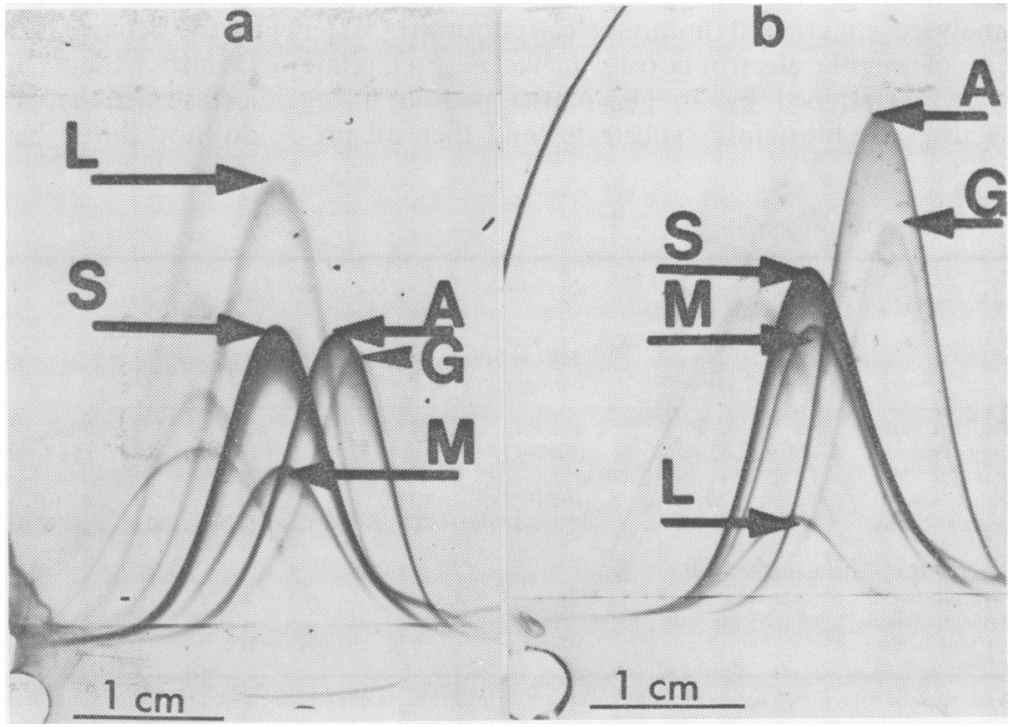




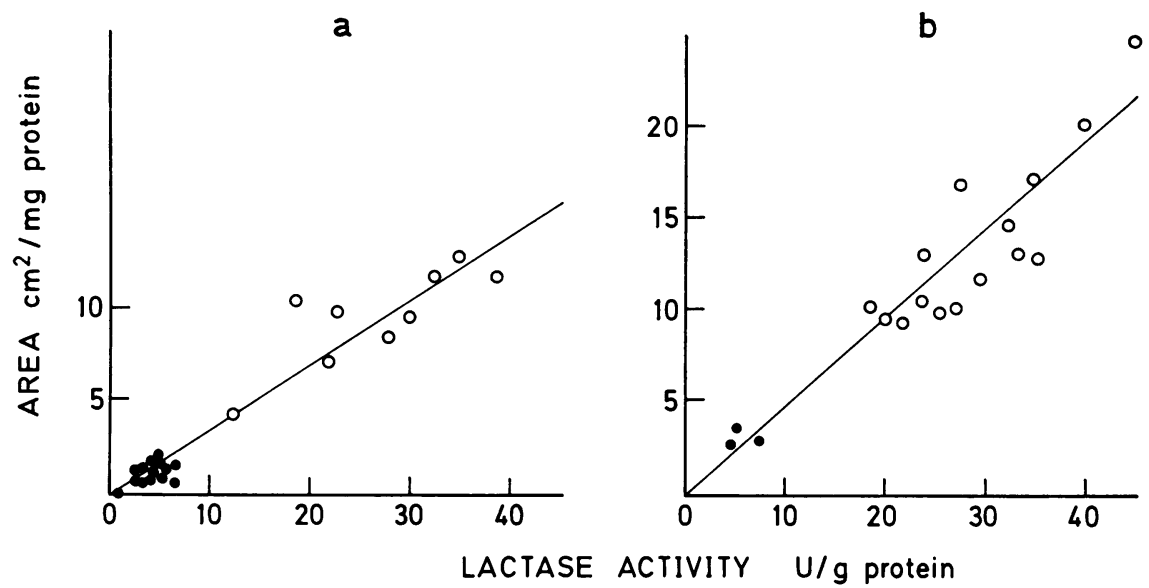

Fig. 3 The amount of lactase protein expressed as area under the precipitate per mg protein versus the specific enzymatic activity. (a) Greenlandic patients, (b) Danish patients. The slope was estimated by the least squares method. Patients with normal lactase activity ( $\bigcirc)$, with hypolactasia (O).

lactase activity and precipitate area is even better than indicated in Tables 1 and 2 and Fig. 3a-b.

\section{Discussion}

Our results demonstrate an unchanged relationship between lactase activity and immunoreactive lactase protein in the adult-type hypolactasia compared with normal subjects in two different populations. It is concluded that the small intestinal brush border membranes of patients with adult-type hypolactasia have a decreased amount of lactase protein and do not contain an inactive enzyme variant with retained antigenic determinants. The presence of a completely altered protein cannot be ruled out in this study.

The most probable reason is a low synthesis of lactase but, theoretically, a specific, increased catabolism of lactase is also possible. These results are in accordance with the conclusions from other studies. $^{45}$ The immunological technique also measures possible inactive, intracellularly localised lactase molecules. Provided that the solubilisation procedure also releases these molecules from the intracellular particles, we can conclude that no significant amount of cross-reacting inactive lactase protein is present in the cell. This makes it unlikely that the hypolactasia state is caused by a block in transfer of lactase protein from an intracellular focus to the brush border membrane.

The patients of this study were selected by the presence of specific low lactase activity in histologically normal biopsies from the proximal part of jejunum. No criteria of lactose malabsorption- that is, flat blood glucose curve during lactose tolerance test and/or abdominal complaints during this test-were included. However, it is likely that our Greenlandic patients also fulfil these criteria, as Asp et al. ${ }^{13}$ have reported that 15 out of 16 patients from the same area in Greenland with specific hypolactasia also fulfil one or both of these specified clinical criteria.

This work was supported by grants No. 512-10175 of the Danish Medical Research Council, No. B 1076 of P Carl Petersens Fond, the Novo Foundation and the Danish Hospital Foundation for Medical Research. Region of Copenhagen, The Faroe Islands and Greenland. The authors are grateful to Ms D Anthonsen and Ms D Rasmussen for skilful technical assistance. Dr O Norén and $\mathrm{Dr}$ H Sjöström are thanked for collaboration in the investigation. The jejunal-ileal shunt operations were performed on surgical department D, Herlev Hospital, Denmark, as a part of the Danish Obesity Project.

\section{References}

${ }^{1}$ Gudmand-Høyer E, Jarnum S. Lactose malabsorption in Greenland Eskimos. Acta Med Scand 1969; 186: 235-7.

${ }^{2}$ Dahlqvist A, Hammond JB, Crane RK, Dunphy JV, Littman A. Intestinal lactase deficiency and lactose intolerance in adults. Preliminary report. Gastroentero$\log y$ 1963; 45: 488-91.

${ }^{3}$ Aurricchio S, Rubino A, Landolt M, Semenza G, Prader A. Isolated intestinal lactase deficiency in the adult. Lancet 1963; 2: 324-6. 
${ }^{4}$ Crane RK, Menard D, Preiser H, Cerda J. The molecular basis of brush border membrane disease. In: Bolis, Hoffman, Leaf. Membranes and diseases, New York: Raven Press, 1976: 229-41.

${ }^{5}$ Freiburghaus AU, Schmitz J, Schindler M, et al. Protein pattern of brush border fragments in congenital lactose malabsorption and in specific hypolactasia of the adult. $N$ Engl J Med 1976; 294: 1030-2.

${ }^{6}$ Gray GM. Congenital and adult intestinal lactase deficiency. N Engl J Med 1976; 294: 1057-8.

'Skovbjerg H, Sjöström H, Norén O, Gudmand-Høyer E. Immunoelectrophoretic studies on human small intestinal brush border proteins. A quantitative study of brush border enzymes from single, small intestinal biopsies. Clin Chim Acta 1979; 92: 315-22.

${ }^{8}$ Sahi T. Progress report. Dietary lactose and the aetiology of human small-intestinal hypolactasia.
Gut 1978; 19: 1074-86.

${ }^{9}$ Skovbjerg H, Norén O, Sjöström H. Immunoelectrophoretic studies of human small intestinal brush border proteins. A qualitative study of the protein composition. Scand J Clin Lab Invest 1978; 38: 723-9.

${ }^{10}$ Dahlquist A. Assay of intestinal disaccharidases. Anal Biochem 1968; 22: 99-107.

${ }^{11}$ Wang CS, Smith RL. Lowry determination of protein in the presence of Triton X-100. Anal Biochem 1975; 63: 414-7.

${ }^{12}$ Asp N-G, Dahlqvist A. Human small intestinal $\beta-$ galactosidases. Specific assay of three different enzymes. Anal Biochem 1972; 47: 527-38.

${ }^{13}$ Asp N-G, Berg N-O, Dahlqvist A, Gudmand-Høyer E, Jarnum S, McNair A. Intestinal disaccharidases in Greenland Eskimos. Scand J Gastroenterol 1975; 10: 513-9. 